\title{
Sharing Good Times and Bad
}

\author{
by Nancy North
}

I HAVE NEVER FELT AT HOME in the city, yet it has always been my home. My family never fit the mold that unconsciously makes city people into desirers of step-savers, plush carpets, and new cars. We enjoy quiet evenings together, nature's variety, and close friendships. It has never mattered whether the neighbor's house was bigger or nicer, we are just thankful for what we have and can share. But like an unseen force, the desire to have more creeps into attitudes. It consumes simple pleasures and causes people to work until they finally break beneath the pressure. It happens to almost everyone, I have even felt myself wanting something just because everyone else has it, even though I realize that such attitudes make us less than our best. Meeting people who seem to be free from the urge to consume and "compete with the Joneses" was perhaps the most rewarding part of my participation in the Foxfire Interim. My encounter with the rural community and its original citizens was like a homecoming.

Simplicity was the first thing that struck me about the people we talked with. From the moment we met they were friendly, open, and honest. Their homes were warm and welcoming, void of extravagance and plush decoration. Most often cheery curtains hung at the windows, an old rocking chair begged to be sat in, and the tantalizing aroma of baking filled the air. In a generous manner, we were always asked to stay for coffee and a sampling of the latest goodies. However, this generosity extends much further than afternoon coffee. It is part of a way of life that has been alive in this people for generations.

In Norway, the homeland, cooperation was a necessity. Farms were small and rocky, barely enough to sustain a family. If crops failed or there was not enough to eat, people had to depend on each other for both physical needs and moral support. When the decision was made to leave the land they had always known and gamble on an unknown place across the sea, they were united in anticipation and fear. No one knew for sure that he, or she, could make a better home in the new land; familial support was often crucial to existence. The hardships of the journey drew people 
closer, and when they finally settled in Winneshiek County, new problems were overcome-together. Theirs was a spirit of goodwill and generosity that grew even after they became established.

The children of these immigrants were taught from a young age to respect others, no matter what their nationality or religion, and learned from the examples of their parents to be generous and willing to help, to be "neighborly." It is these children who have become my friends.

I met Gennie Kroshus and Martina Stoen on my first interview. Gennie's home is perched on the small mountain that cradles the village of Highlandville to the east. Martina's home, the old red-brick bank, lies just below. It still looks slightly business-like on the outside, but the main lobby of the bank has been converted into a cozy kitchen and living room, the office into a bedroom, and the vault into a pantry. A small road climbs the hill above Gennie's white frame house, but it is impassable in winter, so we walked up on a crisp January day to interview her. She greeted us with a smile and in moments I was at ease. My partner Gerry, Gennie and I gathered around the table at the center of the small but homey room that Gennie heats for winter use and began our conversation.

Social functions were a vital part of the rural community. Work was temporarily forgotten, stories swapped, and children and adults had fun together. The churches and schools were the focal point of almost all events.

Both Gennie and Martina were active Luther League members. The group met once a month, first at homes and later at a different church every month. Games such as "Four in a Boat" (disapproved of by the minister because the song sung with it contained the phrase "we don't care what the old folks say!"), "London Bridge," and "Bingo" were played. A lunch was always served, and the minister gave a short sermon addressed to the young folks.

The crowds were huge at these gatherings; Martina and Gennie both estimated that around two hundred people attended. Another source has said that when games were played at the large Big Canoe Church a circle could easily reach twice around the structure. The churches also had activities for adults. Services were held every other Sunday, and there were ladies groups that met regularly. 
Country schools were places where children went to learn during the day, and also where they could gather with their families for special events at other times. Gennie remembers song and dance shows put on by the students under the direction of their teacher. One number she especially recalls was one in which the boys got to wear white overalls and the girls, white dresses. The school was so packed for these shows that "there was scarcely room to breath."

Martina tells of basket socials held at the schools once a year. Their purpose was to raise funds for school supplies for the coming year. Each girl brought a basket filled with a tempting lunch, and young boys and men alike bid for the baskets and the privilege of eating with their owners. Prices normally ranged from $\$ 1.50$ to $\$ 2.00$, which was an outstanding sum. Most of the time boys were too poor to out-bid the men, so if they were lucky some man would buy a basket for them.

The sharing of work was one of the most important things that drew the turn-of-the century community together. There was always work to be done by all members of the family, but both Martina and

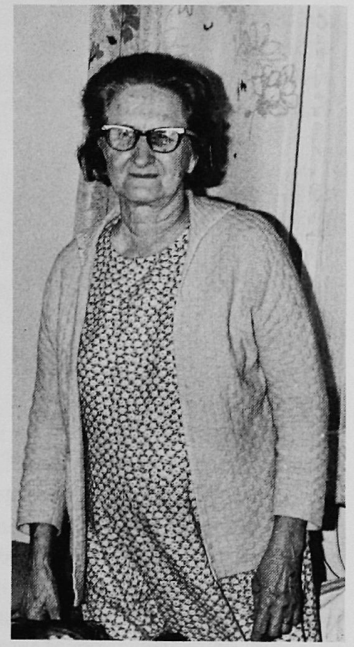

Photograph by Steve Buck

Martina Stoen

Gennie agreed that the oldest children had more to do than the younger ones ever did. Of course, they were "older children" themselves, so that might have some effect on their opinions!

It was common for the children to work out on neighbors' farms, if they were not needed at home. Sometimes they were paid for the work they did, but usually it was taken as a matter of course that if there was work to be done and someone free to do it, it would be done by that person without a second thought. 


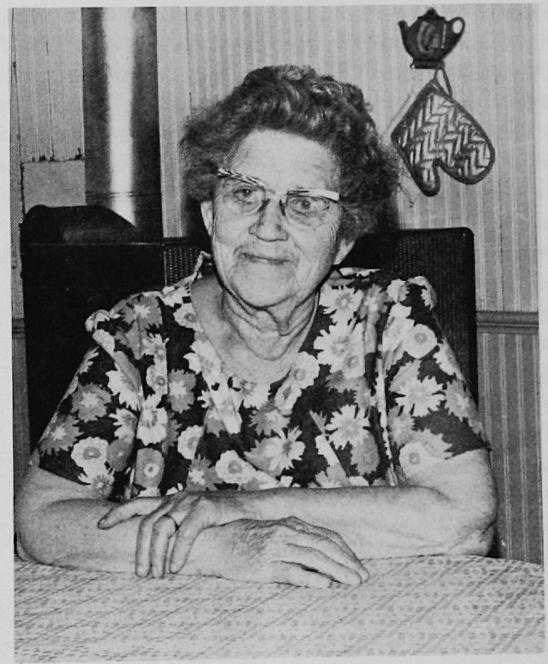

Genevieve Kroshus

Photograph by Steve Buck

Late summer and early fall were busy times of preparation. Women canned meat for the coming winter, and all the able men who had threshing to be done helped with threshing the wheat of the whole community. The men worked steadily in the hot sun, refreshed at noon by huge lunches prepared by the wife of the neighbor on whose farm they were working. Regardless of how many acres he had himself, every man went to every farm.

Times of crisis, such as the flu epidemic of 1918 , were times when members of the community desperately needed each other. Gennie's family were all so sick that a neighbor had to do their chores, and he was so weak himself that when he rode out of the gate to the road he collapsed on his horse and had to trust it to get him home. When members of the family became well enough they often went to other homes to nurse the families who had no one to care for them. 
In another conversation, George Kjome told that his father delivered medicines for the community because there was usually no way for most of the families to get to town. Many people died during the epidemic, leaving homeless children, so families such as Martina's took them in and raised them as their own, even though they already had nine children.

I found the spirit of a pioneer community very much alive in Highlandville today. The friends I have made have shown me that genuine bonds of love and generosity between neighbors are not as rare as I had imagined. They live daily as true neighbors, individuals, yet part of a group of people who feel deeply each other's losses and joys and live in harmony by sensing another's needs and doing their best to fill them.

$$
\text { \# \# }
$$

\section{A Miller's Tale of True Grist}

\section{by Geraldine Schwarz}

ON THE BANKS OF THE UPPER IOWA, fifty-five miles upstream from Decorah, stands the Lime Springs Mill. A sign on the front of the brick veneered building proclaims it was established in 1857. For over a hundred years, this mill was a busy center of activity, but by 1960 portable mills and the steel structure in town had cut so deeply into its business that it was closed.

During the last forty-two years of its operation, Herman Lidtke owned and ran the mill, spending his days grinding buckwheat flour or stock feed and his evenings running the electric power plant connected to the mill, which served Lime Springs and Chester. Now nearly ninety, he speaks with enthusiasm and pride about those arduous days.

Explaining how he became a miller, he says, "I was just sort of a one-horse farmer when I got into this. I married the daughter of the man who owned it, and she was the only kid in the family and the mill went with the deal." He chuckles and adds, "That was the sad part of it."

With obvious respect and admiration, Mr. Lidtke talks about 
Copyright of Annals of Iowa is the property of State of Iowa, by \& through the State Historical Society of Iowa and its content may not be copied or emailed to multiple sites or posted to a listserv without the copyright holder's express written permission. However, users may print, download, or email articles for individual use. 